\title{
Effect of PAC addition in combined treatment of landfill leachate and domestic wastewater in semi-continuously fed batch and continuous-flow reactors
}

\author{
Ferhan Çeçen* and Özgür Aktas \\ Bogaziçi University, Institute of Environmental Sciences, 80815, Bebek, Istanbul, Turkey
}

\begin{abstract}
The combined biological treatability of landfill leachate and domestic wastewater was investigated in both semi-continuously fed batch (SCFB) and continuous-flow (CF) activated sludges with recycle. Powdered activated carbon (PAC) was added in order to investigate the improvement in organic carbon removal and nitrification. The results obtained in SCFB and CF operations were compared to each other. In both types of operations, COD and ammonia removal efficiencies decreased with an increase in the leachate ratio of the total wastewater. As the leachate ratio increased, the positive effect of PAC on COD removal and nitrification became more apparent. In SCFB-type operations, nitrification was more inhibited than in CF operations. Additionally, the enhancement of nitrification was more apparent in $\mathrm{CF}$ operations than in SCFB operations where there was PAC addition. In CF operations, sufficient PAC addition could completely prevent nitrification inhibition and nitrite accumulation was avoided. With regard to nitrification, the positive impact of PAC was observed after some time since inhibition of nitrifiers was more severe than heterotrophs.
\end{abstract}

\section{Nomenclature}

$\mathrm{BOD}_{5} \quad$ 5-day biochemical oxygen demand $\left(\mathrm{mg} \cdot \ell^{-1}\right)$

$\mathrm{CF} \quad$ continuous-flow reactor

COD chemical oxygen demand $\left(\mathrm{mg} \cdot \ell^{-1}\right)$

TCOD total COD

SCOD soluble COD

MLCOD mixed liquor COD

$\mathrm{NO}_{x}-\mathrm{N} \quad$ nitrite and nitrate nitrogen $\left(\mathrm{mg} \mathrm{NO}_{2}-\mathrm{N}+\mathrm{NO}_{3}-\mathrm{N} \cdot \ell^{-1}\right)$

MLSS mixed liquor suspended solid $\left(\mathrm{mg} \cdot \ell^{-1}\right)$

MLVSS mixed liquor volatile suspended solids $\left(\mathrm{mg} \cdot \ell^{-1}\right)$

OUR oxygen uptake rate $\left(\mathrm{mg} \cdot \ell^{-1} \cdot \mathrm{h}^{-1}\right)$

PAC powdered activated carbon

PACT powdered activated carbon treatment

SCFB semi-continuously fed batch reactor

TKN total Kjeldahl nitrogen $\left(\mathrm{mg} \cdot \ell^{-1}\right)$

\section{Introduction}

Sanitary landfill leachate is usually a very high strength wastewater containing many organic and inorganic constituents. Due to the high strength of leachate, care should be given in combined treatment of leachate and domestic wastewater in an activated sludge system. A previous study on combined landfill leachate and domestic wastewater treatment demonstrated that these could be treated at suitable mixing ratios (Çeçen and Çakiroglu, 2001). However, in that study leachates were shown to contain nonbiodegradable matter which could not be removed by biological treatment alone. Also an increase in leachate ratio caused a reduction in the overall organic substrate removal rate in batch reactors. In addition to this, a severe nitrification inhibition may be observed in high-strength leachates due to the high free ammonia levels and

* To whom all correspondence should be addressed.

푱(90) 21226315 00; fax (90) 212257 5033; e-mail: cecenf@ boun.edu.tr Received 24 July 2000; accepted in revised form 23 November 2000. presence of other inhibitors. Activated carbon addition in the form of PAC is known for its ability to enhance biological treatment efficiency, remove refractory organic compounds and to enhance nitrification. Therefore, PAC addition to activated sludge could also be tested in leachate treatment systems (U.S. EPA, 1995; Kang et al., 1990).

Organic matter removal in a PACT system is a combination of adsorption and biodegradation. Activated carbon in conjunction with activated sludge increases the removal efficiency by adsorbing non-biodegradable, toxic and/or inhibitory organics and also some metals. Many researchers have suggested that a synergy exists between activated carbon and micro-organisms. Thus, the PACT system could remove an organic compound more efficiently than would be expected from either biodegradation or adsorption alone. The mechanism consists of the stimulation of biological activity by bioregeneration of PAC. Activated carbon provides an attachment surface for micro-organisms and protects them from shock loadings of toxic and inhibitory materials, whereas micro-organisms bioregenerate the activated carbon (Sublette et al., 1982, Marquez and Costa, 1996; Kim et al., 1997; Jonge et al., 1996; Orhansky and Narkis, 1997).

Many studies in literature also showed that nitrification was enhanced by the addition of PAC to activated sludge ( $\mathrm{Ng}$ et al., 1987, Ng and Stenstrom, 1987; Specchia and Gianetto, 1984). The most probable reason was the removal of toxic and inhibitory organics and inorganics by PAC ( $\mathrm{Ng}$ et al., 1987, $\mathrm{Ng}$ and Stenstrom, 1987). The majority of studies deal with nitrification enhancement in industrial wastewater treatment and there is a lack of information on nitrification in landfill leachate treatment in the case of PAC addition.

The objective of this study was the investigation of PAC addition in combined biological treatment of sanitary landfill leachate and domestic wastewater. In another study (Aktas and Çeçen, 2001), adsorption isotherms were shown and the effect of PAC in batch reactors was discussed in detail. On the other hand, this study addressed the impact of PAC under steady operating 


\begin{tabular}{|c|c|}
\hline \multicolumn{2}{|c|}{$\begin{array}{c}\text { TABLE } 1 \\
\text { Characterisation of landfill leachate }\end{array}$} \\
\hline $\mathrm{pH}$ & 8.2 \\
\hline TCOD $\left(\mathrm{mg} \cdot \ell^{-1}\right)$ & 10750 \\
\hline $\operatorname{SCOD}\left(\mathrm{mg} \cdot \ell^{-1}\right)$ & 9070 \\
\hline $\mathrm{BOD}_{5}\left(\mathrm{mg} \cdot \ell^{-1}\right)$ & 6380 \\
\hline TKN $\left(\mathrm{mg} \cdot \ell^{-1}\right)$ & 2031 \\
\hline $\mathrm{NH}_{4}-\mathrm{N}\left(\mathrm{mg} \cdot \ell^{-1}\right)$ & 2002 \\
\hline $\mathrm{NO}_{\mathrm{x}} \mathrm{N}\left(\mathrm{mg} \cdot \ell^{-1}\right)$ & 128 \\
\hline Total $\mathrm{P}\left(\mathrm{mg} \cdot \ell^{-1}\right)$ & 6.8 \\
\hline $\mathrm{Cl}^{-}\left(\mathrm{mg} \cdot \ell^{-1}\right)$ & 4322 \\
\hline Alkalinity $\left(\mathrm{mg} \mathrm{CaCO}_{3} \cdot \ell^{-1}\right)$ & 10600 \\
\hline Total solids $\left(\mathrm{mg} \cdot \ell^{-1}\right)$ & 17326 \\
\hline $\operatorname{TSS}\left(\mathrm{mg} \cdot \ell^{-1}\right)$ & 1013 \\
\hline $\operatorname{VSS}\left(\mathrm{mg} \cdot \ell^{-1}\right)$ & 786 \\
\hline Salinity (\%) & 18.2 \\
\hline Conductivity $\left(\mathrm{mS} \cdot \mathrm{cm}^{-1}\right)$ & 29.5 \\
\hline
\end{tabular}

conditions and aimed at demonstrating the differences between semi-continuous and continuous-flow operations. Also investigated was whether PAC addition could relieve the negative impact of leachate when the ratio of leachate was increased. This impact was studied with regard to both organic carbon removal and nitrification.

\section{Materials and methods}

\section{Wastewater characteristics}

\section{Leachate characteristics}

Throughout the study, landfill leachate was mixed with domestic wastewater at certain volumetric ratios and its treatability was studied in activated sludge systems (Aktas,1999). The leachate sample was taken from the Kemerburgaz landfill in Istanbul which receives municipal solid wastes and was characterised as in Table 1. The concentrations reflected the average of multiple analyses during the storage period at $4^{\circ} \mathrm{C}$.

Leachate quality indicated the degree of stabilisation within a landfill (Krug and Ham, 1997). As seen in Table 1, a relatively biodegradable wastewater was received based on the $\mathrm{BOD}_{5} / \mathrm{COD}$ ratio (Quasim and Chiang, 1994). In all leachate samples TKN concentration was high and a major part of it consisted of ammonium nitrogen showing the hydrolysis of organic nitrogen into ammonia nitrogen.

\section{Domestic wastewater}

Domestic wastewater was prepared synthetically as a stock solution having a total COD of $10000 \mathrm{mg} \cdot \ell^{-1}$, TKN of $1060 \mathrm{mg} \cdot \ell^{-1}$, phosphorus of $812 \mathrm{mg} \cdot \ell^{-1}$ and $\mathrm{pH}$ 7.1. The solution comprised 6000 $\mathrm{mg} \cdot \ell^{-1} \mathrm{CH}_{3} \mathrm{COONa}, 5600 \mathrm{mg} \cdot \ell^{-1}$ glucose, $2000 \mathrm{mg} \cdot \ell^{-1}$ peptone, 5 $000 \mathrm{mg} \cdot \ell^{-1}\left(\mathrm{NH}_{4}\right)_{2} \mathrm{SO}_{4}, 2000 \mathrm{mg} \cdot \ell^{-1} \mathrm{KH}_{2} \mathrm{PO}_{4}, 2000 \mathrm{mg} \cdot \ell^{-1} \mathrm{~K}_{2} \mathrm{HPO}_{4}, 2$ $000 \mathrm{mg} \cdot \ell^{-1} \mathrm{MgSO}_{4} \cdot 7 \mathrm{H}_{2} \mathrm{O}, 600 \mathrm{mg} \cdot \ell^{-1} \mathrm{CaCl}_{2} \cdot 2 \mathrm{H}_{2} \mathrm{O}, 200 \mathrm{mg} \cdot \ell^{-1}$ $\mathrm{FeCl}_{3} .6 \mathrm{H}_{2} \mathrm{O}$. This solution was diluted to a typical domestic wastewater COD of $500 \mathrm{mg} \cdot \ell^{-1}$.

Although leachate constituted a small percentage of the total wastewater, it contributed much to the initial COD of the wastewater. For example, when leachate made up $6.7 \%$ of the mixture (1/15 of total wastewater) on a volumetric basis, its contribution to the initial COD was as high as $42 \%$.

\section{Experimental steps}

In a previous study it was shown that in an aerated batch activated sludge reactor the adsorption onto PAC was much higher than that predicted by isotherms (Aktas and Çeçen,2000). In those batch experiments PAC did not considerably influence the biodegradation rate of organics. PAC was mainly effective in the adsorption of residual non-biodegradable matter. Although batch tests may clarify substrate removal kinetics, they do not provide sufficient information about treatability in continuous-flow systems since transient conditions are present in these batch reactors with respect to substrate and biomass composition.

Therefore, in this study the effect of PAC addition was first examined in semi-continuously fed batch reactors (SCFB) as outlined in (a) below. The activated carbon used throughout the study was Norit SA 4 in powdered form. PAC was dried at $103^{\circ} \mathrm{C}$ before use in experiments. In each case, the results obtained in activated sludge systems (AS) and in PAC-added activated sludge systems (AS+PAC) were compared to each other in terms of organics and nitrogen removal. The data were also subjected to statistical analysis and the differences were tested for significance at a level of $95 \%$ confidence using the paired t-test. In the next step, experiments were continued in a continuous-flow (CF) activated sludge reactor with sludge recycle as outlined in (b) below. Results for COD removal, ammonium nitrogen removal, $\mathrm{NO}_{\mathrm{x}}-\mathrm{N}$ production, nitrite build-up and OUR were interpreted along with data generated from previous batch experiments.

In each SCFB run and at the beginning of the CF operation a fresh sludge was taken for seeding purposes. This seed sludge was obtained from a batch activated sludge system fed with synthetic domestic wastewater at a loading rate of $500 \mathrm{mg} \mathrm{COD} \cdot \ell^{-1} \cdot \mathrm{d}^{-1}$. In that system the sludge age was adjusted to $20 \mathrm{~d}$ in order to enhance the activity of nitrifiers.

\section{a) Experiments in SCFB activated sludge reactors}

In SCFB operation, a batch reactor is fed and the effluent is withdrawn intermittently. At the end, steady-state conditions are reached and this operation simulates a continuous-flow operation. In the present study, this operation was applied since it allowed for better and easier control in simultaneous monitoring of AS and AS+PAC reactors.

For this purpose, two batch plexiglass reactors were used, each having a liquid volume of $2 \ell$. One of them was operated as an AS and to the other, PAC was also added (AS+PAC). The operational conditions in these runs can be followed from Table 2. In total, four runs (SCFB Runs 1-4) were conducted. The influent was composed of leachate and domestic wastewater mixed at certain ratios. This influent was discontinuously fed once a day and the effluent was withdrawn on the next day. The hydraulic residence time was adjusted to $32 \mathrm{~h}$ by discharging $1.5 \mathrm{l}$ of the supernatant liquid daily. Mainly the reduction in organic matter and nitrogen was investigated. For this purpose, TCOD, SCOD, pH, MLSS, MLVSS, TKN, $\mathrm{NH}_{4}^{-}$ $\mathrm{N}, \mathrm{NO}_{x}-\mathrm{N}, \mathrm{NO}_{2}-\mathrm{N}$ measurements were made. The response of activated sludge to substrate dosing was also monitored by daily OUR measurements from the mixed liquor. As seen in Table 2 a, the sludge age $q_{c}$, was adjusted to $20 \mathrm{~d}$ in SCFB Runs 2 and 4, and to $10 \mathrm{~d}$ in SCFB Run 3 which was fed with a high COD wastewater. When the sludge age was adjusted to $20 \mathrm{~d}$, one twentieth of the total mixed liquor was wasted daily. Only in SCFB Run 1, which was regarded as a preliminary run, no sludge wastage was done. Since in all other runs PAC was wasted daily with the withdrawn sludge, a new PAC addition was made daily and the wasted amount was replaced. 


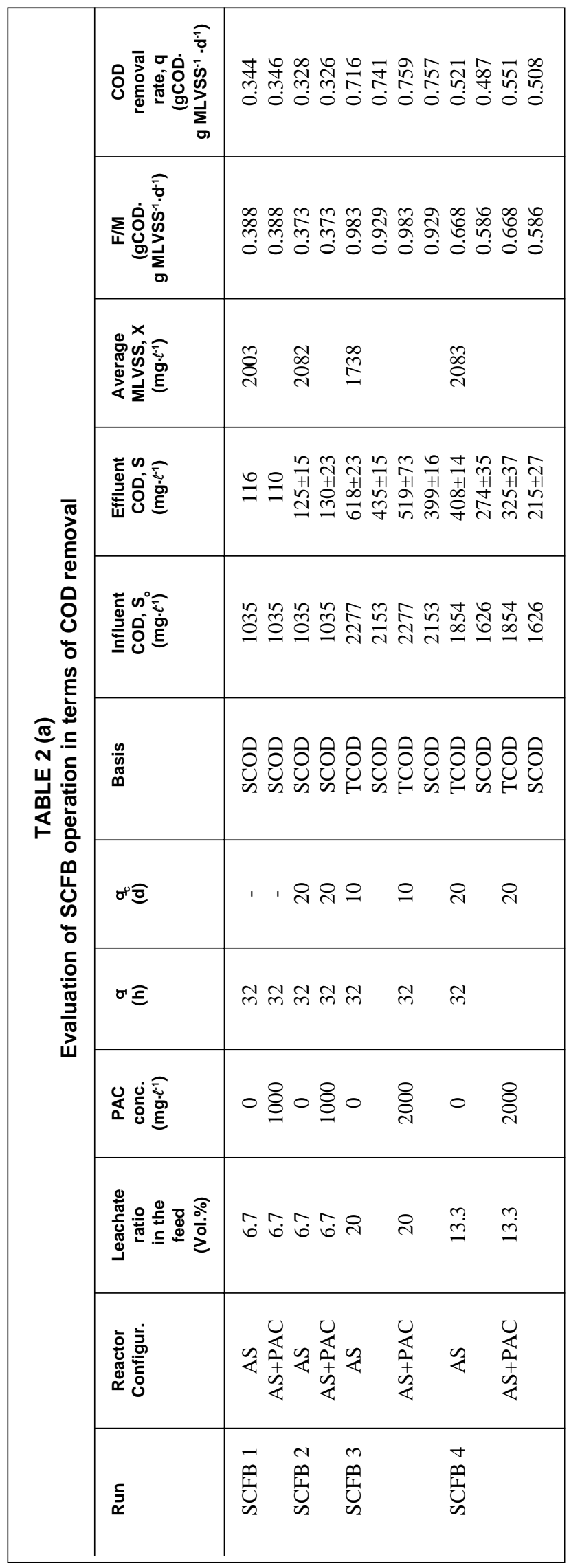

\begin{tabular}{|c|c|c|}
\hline \multirow{11}{*}{ 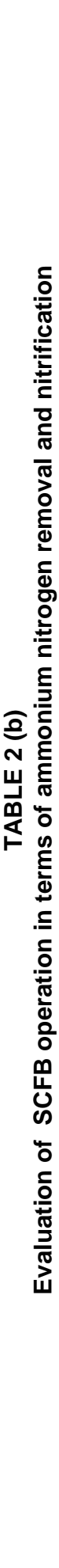 } & 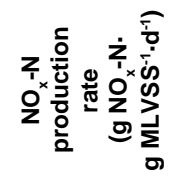 & 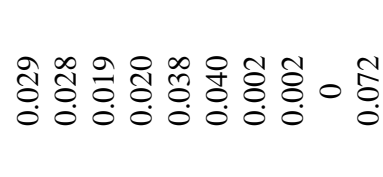 \\
\hline & 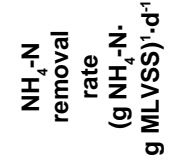 & 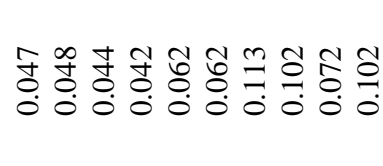 \\
\hline & 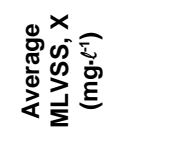 & ڤి \\
\hline & 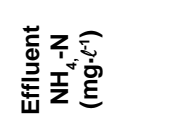 & 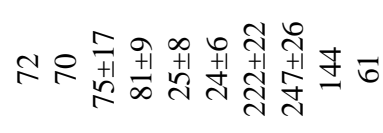 \\
\hline & 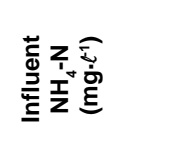 & 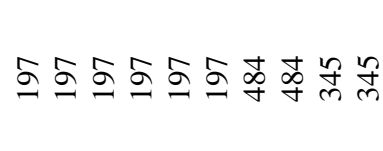 \\
\hline & 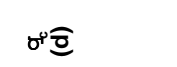 & ' 유유유으으규 \\
\hline & rહ & 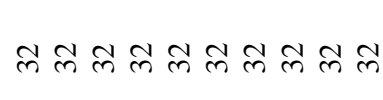 \\
\hline & 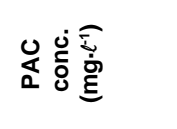 & 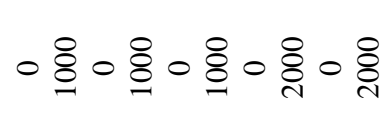 \\
\hline & 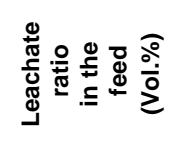 & 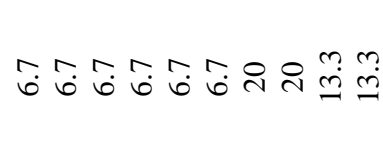 \\
\hline & 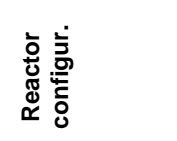 & 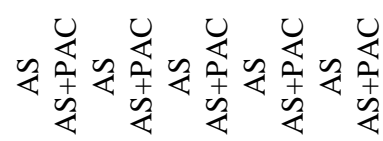 \\
\hline & $\underset{\widetilde{s}}{\tilde{x}}$ & 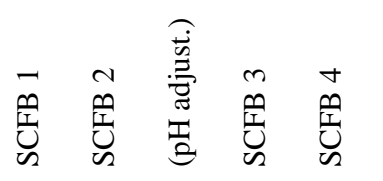 \\
\hline
\end{tabular}




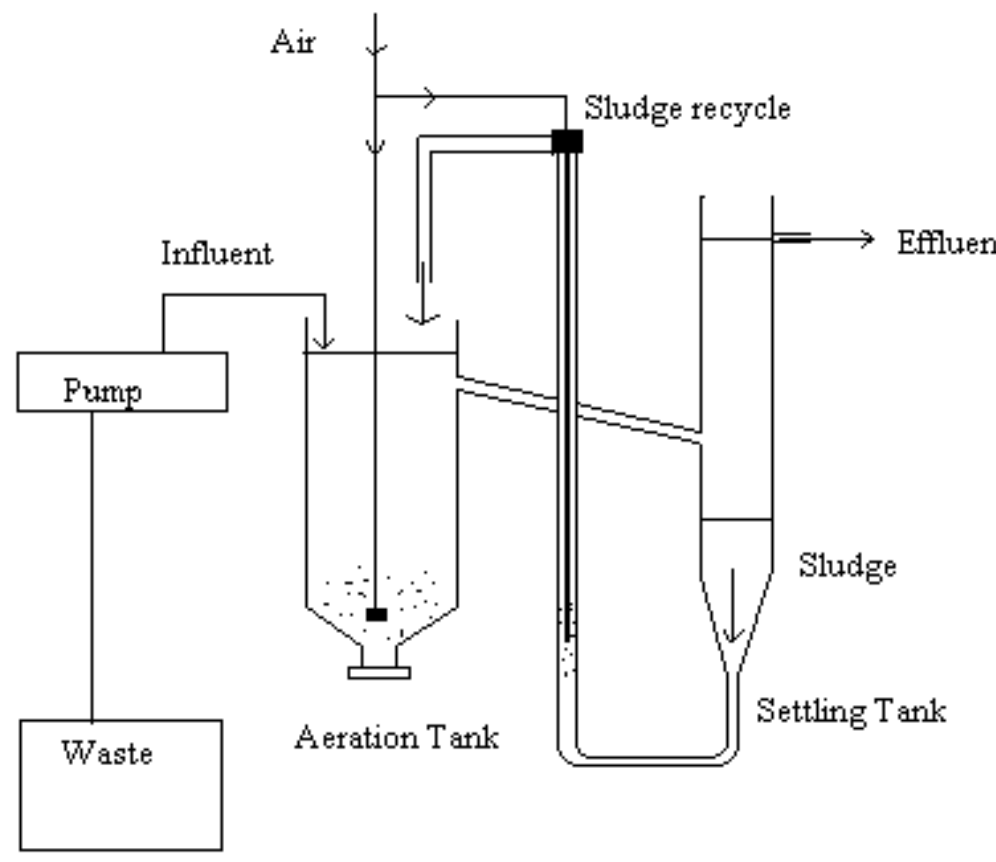

Figure 1

Set-up for the CF experiments

\section{b) Experiments in the CF activated sludge unit}

In order to simulate the impact of PAC in full-scale activated sludge operation, a lab-scale CF was employed (Fig.1). The aeration and the settling tanks had volumes of 3.61 and $2.5 \ell$, respectively. The sludge was recycled to the aeration tank by means of an air lift.

A feed composed of leachate and domestic wastewater was continuously supplied to the system. The operational conditions may be seen in Table $3 a$ and $b$. Influent and effluent TCOD, SCOD, $\mathrm{pH}$, MLSS, MLVSS, TKN, $\mathrm{NH}_{4}-\mathrm{N}, \mathrm{NO}_{\mathrm{x}}-\mathrm{N}, \mathrm{NO}_{2}-\mathrm{N}$ were measured regularly. The response of activated sludge to substrate dosing was also monitored by daily OUR measurements from the mixed liquor. The operation was divided into two periods as follows:

Period 1: The operation was first started with a feed in which the volumetric leachate ratio was about $6.7 \%$ as in the previous SCFB Runs 1 and 2 . This period lasted for $27 \mathrm{~d}$. On the $19^{\text {th }}$ day of normal operation, PAC was added to the aeration tank to yield 2000 $\mathrm{mg} \cdot \ell^{-1}$ and its influence on effluent quality was examined.

Period 2: On the $27^{\text {th }}$ day of operation, the leachate ratio in the influent was increased to $13.3 \%$ in accordance with previous semicontinuous runs. When steady-state was achieved on the $36^{\text {th }}$ day, a second PAC addition was made to the aeration tank to yield an additional PAC of $2000 \mathrm{mg} \cdot \ell^{-1}$, thus the total PAC concentration was increased to $4000 \mathrm{mg} \cdot \ell^{-1}$. The operation was stopped on the $44^{\text {th }}$ day when the effect of this addition was no longer observed.

\section{Analytical methods}

Analyses were carried out in accordance with Standard Methods, 1989. COD analyses were performed by the dichromate closed reflux method. Nitrite accumulation interfered in COD analyses and therefore COD data were corrected (Aktas, 1999) by considering the nitrite nitrogen concentrations.

Total COD (TCOD) was defined as the COD of the unfiltered raw sample. Soluble COD (SCOD) was the COD of the supernatant filtered through $0.45 \mathrm{~mm}$ Millipore filter. SCOD was taken as the main organic parameter throughout the study.

$\mathrm{NH}_{4}-\mathrm{N}$ analysis was carried out by the Gerhardt Vapodest 12 ammonia distillation apparatus and subsequent titration. TKN analysis was done by the same procedure after digestion of samples with Gerhardt Kjeldatherm. The $\mathrm{NO}_{x}-\mathrm{N}\left(\mathrm{NO}_{2}-\mathrm{N}+\mathrm{NO}_{3}-\mathrm{N}\right)$ concentration was determined by the Devarda's Alloy Reduction Method and subsequently by the same procedure as for ammonia. $\mathrm{NO}_{2}-\mathrm{N}$ concentrations in the samples were measured spectrophotometrically using Hach DR/3 Spectrophotometer and Nitriver 2 test kits.

MLSS analysis was carried out by drying the residue on filter paper (Millipore $0.45 \mu \mathrm{m}$ ) for one hour at $103^{\circ} \mathrm{C}$. MLVSS analyses were carried out by igniting the MLSS analysis residue for $30 \mathrm{~min}$ at $600^{\circ} \mathrm{C}$. Since PAC contributed to MLVSS measurements, the biomass-MLVSS in the PAC sludge of the continuousflow reactor was determined separately according to a procedure proposed in the literature (Arbuckle and Griggs,1982). In accordance with this procedure tests for MLSS, MLVSS at $400^{\circ} \mathrm{C}$ and MLVSS at $550^{\circ} \mathrm{C}$ were performed on both the PAC sludge and the PAC used. By incorporating the volatile suspended solids due to PAC, the biomass-MLVSS was estimated.

For $\mathrm{pH}$ measurement the $\mathrm{pH}$ meter Orion SAS20 was used. $\mathrm{BOD}_{5}$ analysis was performed by the dilution method. OUR in the activated sludge reactors was measured automatically by WTW Microprocessor Oximeter Oxi 3000. Details are outlined in a previous study (Aktas, 1999).

\section{Results and discussion}

\section{SCFB activated sludge operation}

The total period in each semi-continuously fed batch run was long enough to reach pseudo steady-state conditions. Steady state was defined as the condition when a constant COD level was reached in the effluent. Since MLVSS was a disputable parameter and was subject to errors, MLCOD was occasionally measured from the agitated activated sludge. MLCOD included both the total COD of the bulk liquid and the biomass-COD. Steady state condition was also checked with MLCOD measurements. Following the start of intermittent feeding, steady state was achieved after two or three hydraulic residence times ( 3 to $4 \mathrm{~d}$ ) had passed.

In Tables $2 \mathrm{a}$ and $\mathrm{b}$ the operational conditions and results are summarised with respect to organics removal and nitrogen removal, respectively. The effluent COD values in Table $2 \mathrm{a}$ reflected the mean COD at pseudo steady-state conditions. The F/M value represented the food-to micro-organism ratio, the COD loading per amount of MLVSS. Also in the AS+PAC reactors the same MLVSS concentration was assumed to exist as in AS reactors. The substrate removal rate, $\mathrm{q}$, was calculated as shown in Eq. (1). Correspondingly, in AS+PAC reactors the substrate removal rates were calculated for comparative purposes.

$$
q=\frac{S o-S}{q \cdot X}
$$

where:

q substrate removal rate $\left(\mathrm{g} \mathrm{COD} \cdot \mathrm{gMLVSS}^{-1} \cdot \mathrm{d}^{-1}\right)$ 


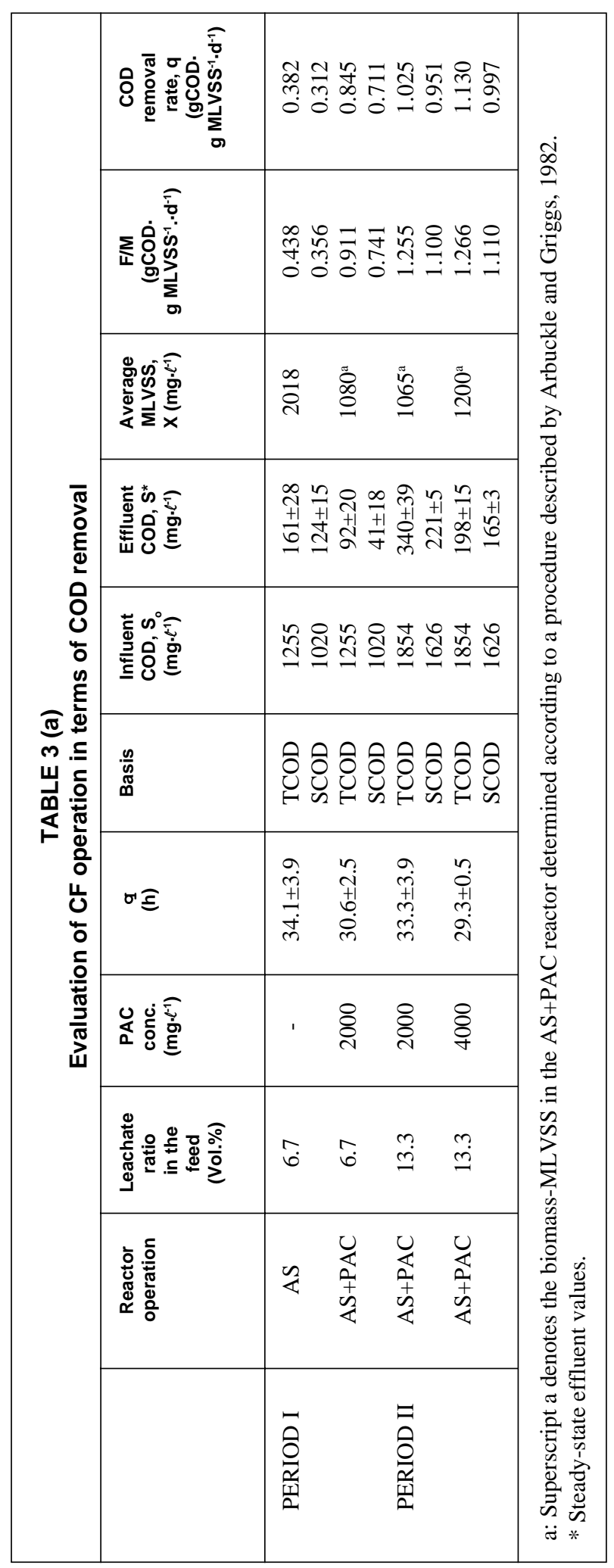

\begin{tabular}{|c|c|c|c|}
\hline \multirow{10}{*}{ 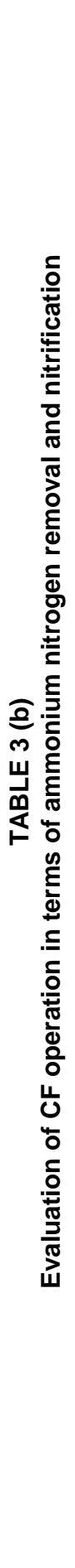 } & 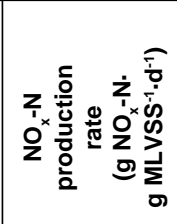 & 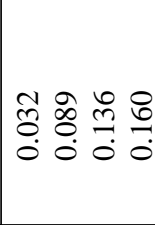 & 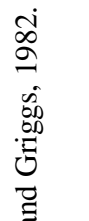 \\
\hline & 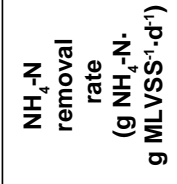 & 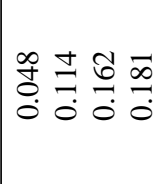 & 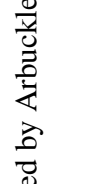 \\
\hline & 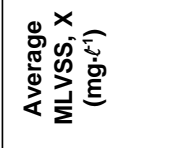 & 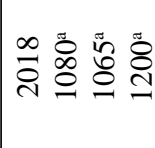 & $\begin{array}{l}\overrightarrow{0} \\
0 \\
0 \\
0 \\
0 \\
0 \\
0\end{array}$ \\
\hline & 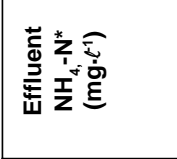 & 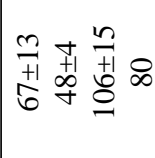 & $\begin{array}{l}0 \\
0 \\
0 \\
\sigma \\
0 \\
00 \\
\Xi \\
=\end{array}$ \\
\hline & 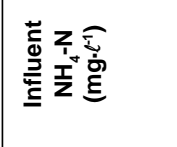 & 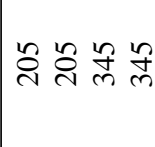 & 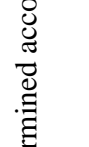 \\
\hline & б조 & 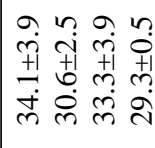 & 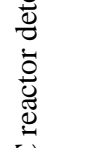 \\
\hline & 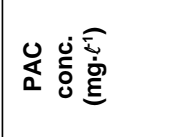 & 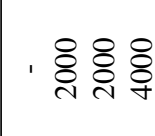 & 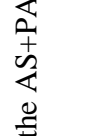 \\
\hline & 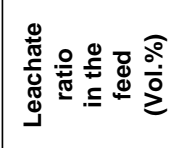 & $\hat{\sigma} \hat{\sigma} \stackrel{n}{=} \stackrel{m}{\dddot{m}}$ & $\begin{array}{l}= \\
n \\
n \\
\sum_{1}^{2} \\
\sum_{i=1}\end{array}$ \\
\hline & 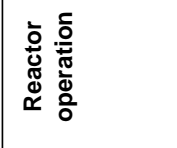 & 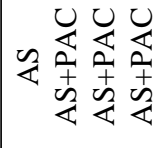 & 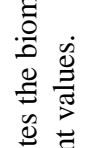 \\
\hline & & 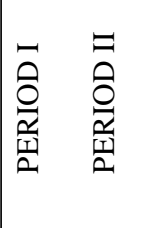 & 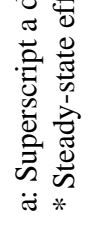 \\
\hline
\end{tabular}


$\mathrm{S}$ influent COD concentration $\left(\mathrm{mg} \cdot \ell^{-1}\right)$

$\mathrm{S}$ effluent steady-state COD concentration $\left(\mathrm{mg} \cdot \ell^{-1}\right)$

$\mathrm{X}$ average biomass concentration during a run (mg.MLVSS: $\left.\ell^{-1}\right)$

$q$ hydraulic retention time (h)

Evaluation of effluent SCOD data (Table 2 a) led to the conclusion that in the effluent mainly nonbiodegradable COD was left over. As the ratio of leachate increased, a higher residual substrate concentration was observed. In previous batch studies it was shown that this leachate possessed an inert COD fraction of about $30 \%$ and that the rate of COD removal in a batch reactor could be described by a first-order model incorporating this fraction (Aktas and Çeçen, 2001). Within the scope of those experiments it was assumed that all of the residual SCOD seen in the effluent was of substrate origin (Aktas and Çeçen, 2001) since in our experiments no evidence was provided that soluble microbial products (SMP) were generated.

SCFB Run 1 was a preliminary run lasting for $5 \mathrm{~d}$. At the beginning PAC was added to the AS+PAC reactor only to yield a constant concentration of 1000 $\mathrm{mg} \cdot \ell^{-1}$ in the aeration tank. Although a slight improvement in COD removal was observed on the next day, in the succeeding days the differences between the AS and $\mathrm{AS}+\mathrm{PAC}$ reactors diminished and finally the same levels were reached with respect to COD (Table 2a) and $\mathrm{NH}_{4}-\mathrm{N}$ and $\mathrm{NO}_{x}-\mathrm{N}$ (Table $2 \mathrm{~b}$ ).

The semi-continuous operation lasted for $35 \mathrm{~d}$ in SCFB Run 2, for $18 \mathrm{~d}$ in SCFB Run 3 and for $11 \mathrm{~d}$ in SCFB Run 4. Figures 2, 3 and 4 illustrate the profiles in these runs.

In SCFB Run 2 the ratio of leachate was the same as in SCFB Run 1 (Figs. 2 a, b, c). PAC was added in small amounts to the AS+PAC reactor daily in order to compensate for the PAC loss with the daily wasted sludge. The effluent SCOD decreased to about $125 \pm 15$ $\mathrm{mg} \cdot \ell^{-1}$ and $130 \pm 23 \mathrm{mg} \cdot \ell^{-1}$ in the reactors $\mathrm{AS}$ and AS+PAC, respectively, as followed from Table $2 \mathrm{a}$. These differences were statistically not significant. As seen in Fig. 2b, the OUR profiles in both reactors were also close to each other. The only considerable difference arose after the shock PAC addition of 1000 $\mathrm{mg} \cdot \ell^{-1}$ on the $15^{\text {th }}$ day, but it did not last long.

In addition to this, at this leachate ratio of $6.7 \%$, PAC addition to the AS+PAC reactor (Table 2b) neither improved $\mathrm{NH}_{4}-\mathrm{N}$ removal nor enhanced the production of $\mathrm{NO}_{\mathrm{x}}-\mathrm{N}$ (Figs. $2 \mathrm{c}$ and d). Analyses by the paired t-test indicated no significant differences between the AS and AS+PAC reactors with respect to both $\mathrm{NH}_{4}-\mathrm{N}$ and $\mathrm{NO}_{x}-\mathrm{N}$. In SCFB Runs 1 and 2 the feed $\mathrm{pH}^{4}$ was brought near neutrality in order to prevent free ammonia inhibition seen in batch operation (Aktas and Çeçen,2000). But in this case, $\mathrm{pH}$ decreased below 5 and a serious nitrite build-up of up to 80 to $100 \mathrm{mg} \mathrm{NO}-\mathrm{N} \cdot \ell^{-1}$ took place in the reactors. Correspondingly, the free nitrous acid (FNA) concentrations rose to $3.25 \mathrm{mg} \cdot \ell^{-1}$ which could be inhibitory to both Nitrosomonas and Nitrobacter (Anthonisen et al.,1976). Therefore on the $23^{\text {rd }}$ day,
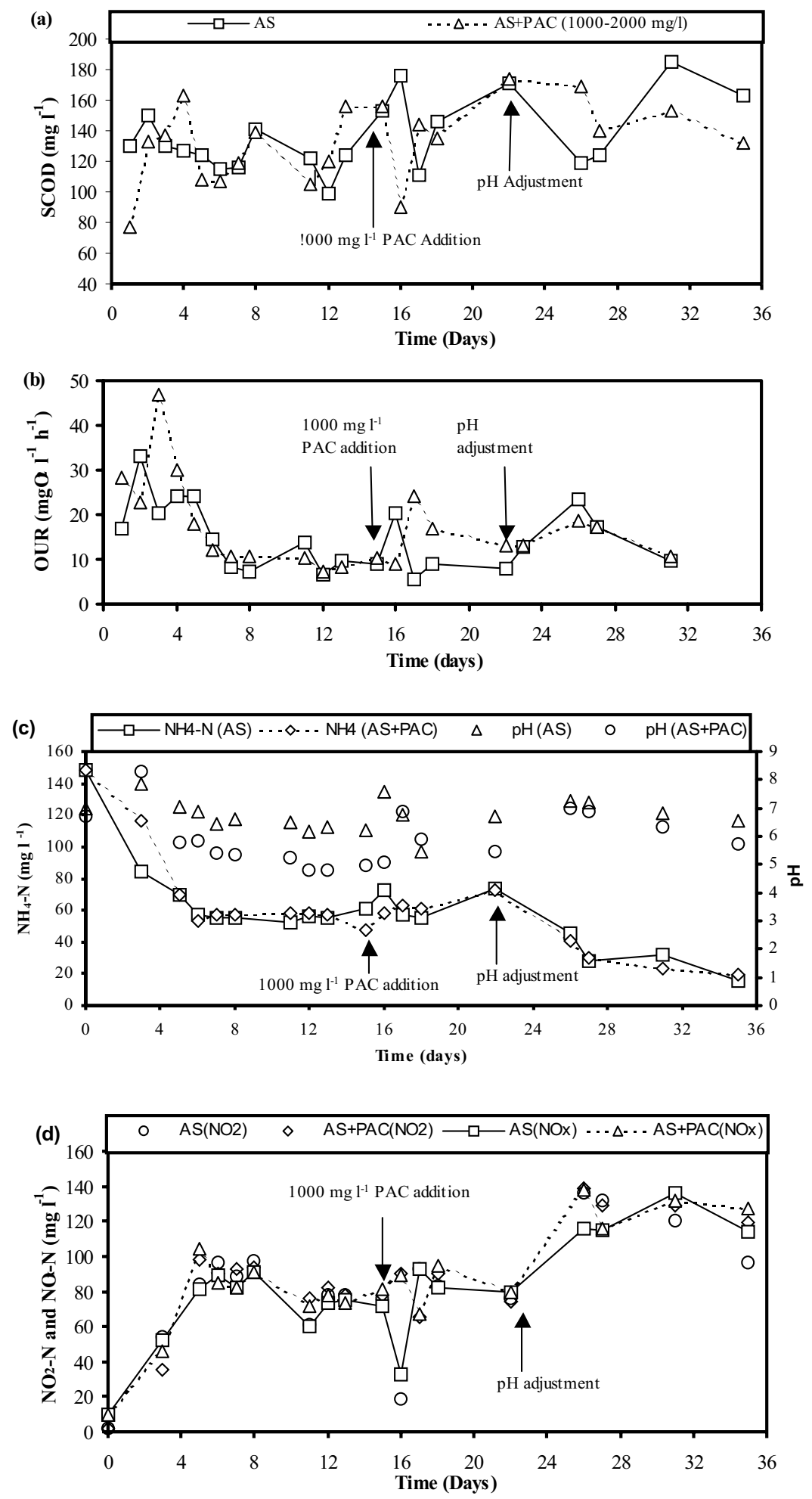

Figure 2

Profiles after the start-up of SCFB Run 2 in AS and AS+PAC reactors (with initial $P A C$ conc. of $1000 \mathrm{mg} \cdot \ell^{1}$ in $A S+P A C$ reactor and feed concentrations of TCOD $1338 \mathrm{mg} \cdot \ell^{1}, \mathrm{SCOD} 1035 \mathrm{mg} \cdot \ell^{1}, \mathrm{TKN} 265 \mathrm{mg} \cdot \ell^{1}, \mathrm{NH}_{4}-\mathrm{N} 197 \mathrm{mg} \cdot \ell^{1}, \mathrm{NO}_{\mathrm{x}}-\mathrm{N} 15$ $m g \cdot \ell^{1}$ and feed $p H$ of 7.17$)$.

(a) Final soluble $C O D(S C O D)$ concentrations

(b) OURs in the reactors

(c) Final $\mathrm{NH}_{4}-\mathrm{N}$ concentrations and $\mathrm{pH}$ in the reactors

(d) Final $\mathrm{NO}_{x}-\mathrm{N}$ and $\mathrm{NO}_{2}-\mathrm{N}$ concentrations 
(a)

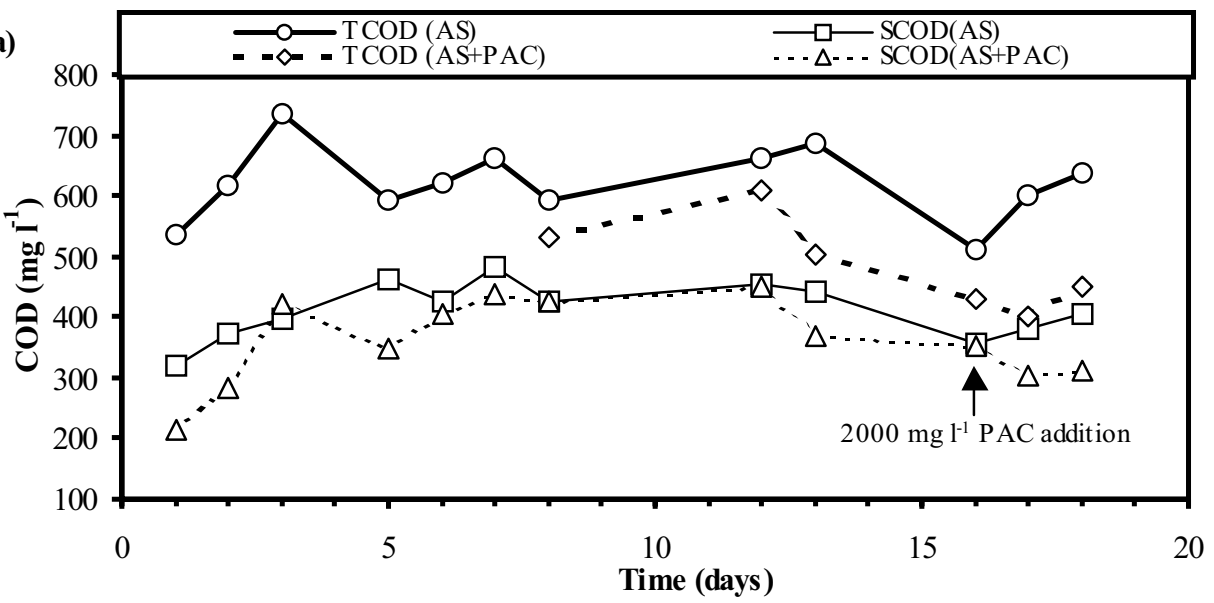

(b)

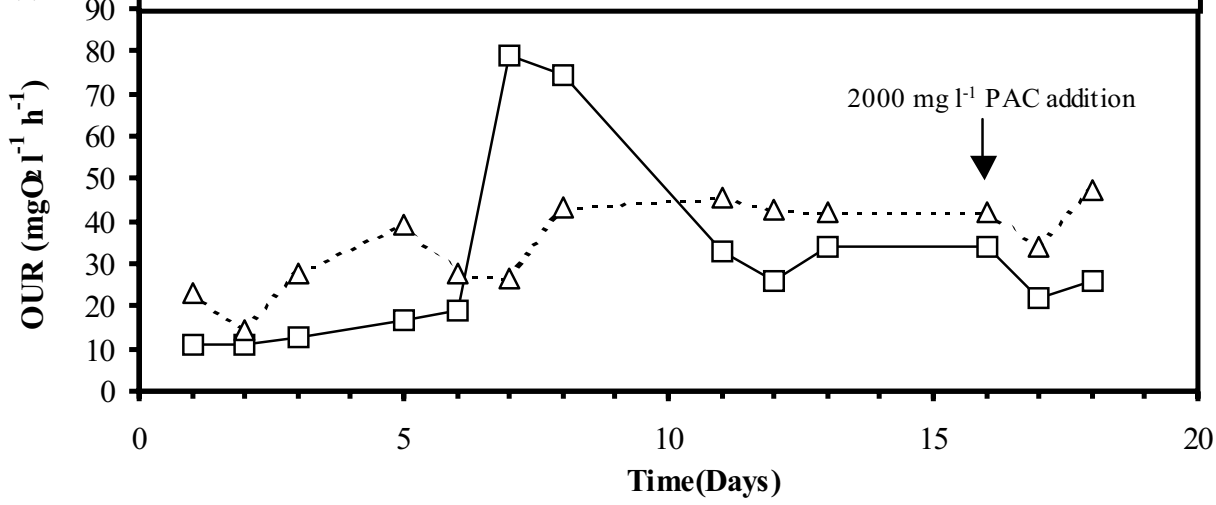

(c)

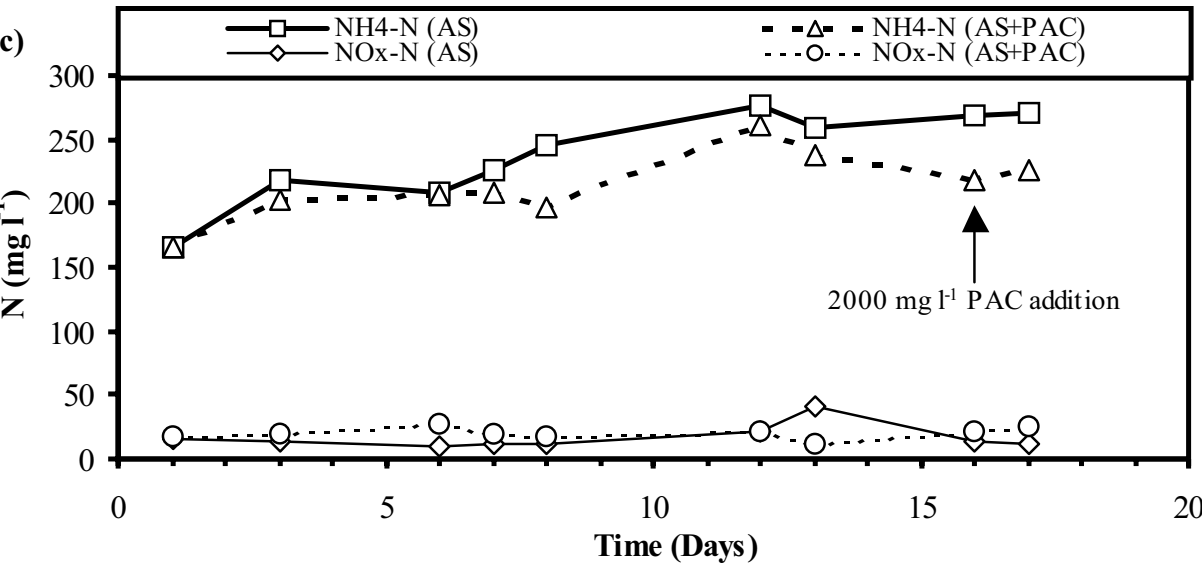

Figure 3

Profiles after the start-up of SCFB Run 3 in AS and AS+PAC reactors (with initial $P A C$ conc. of $2000 \mathrm{mg} \cdot \ell^{1}$ in $A S+P A C$ reactor and feed concentrations of TCOD $2277 \mathrm{mg} \cdot \ell^{1}, S C O D 2153 \mathrm{mg} \cdot \ell^{1}, \mathrm{TKN} 542 \mathrm{mg} \cdot \ell^{1}, \mathrm{NH}_{4}-\mathrm{N} 484 \mathrm{mg} \cdot \ell^{1}, \mathrm{NO}_{x}-\mathrm{N} 12$ $\mathrm{mg} \cdot \ell^{1}$ and feed $\mathrm{pH}$ of 7.62 )

(a) Final total $C O D(T C O D)$ and soluble $C O D(S C O D)$ concentrations

(b) OURs in the reactors

(c) Final $\mathrm{NH}_{4}-\mathrm{N}$ and $\mathrm{NO}_{x}-\mathrm{N}$ concentrations
$\mathrm{pH}$ adjustments were made and nitrification improved obviously (Figs. 2c and d). $\mathrm{NH}_{4}-\mathrm{N}$ concentrations decreased from about 80 to about $25 \mathrm{mg} \cdot \ell^{-1}$ in both the AS and AS+PAC reactors (Fig. 2c). FNA concentrations were decreased to $0.6 \mathrm{mg} \cdot \ell^{-1}$ which was not inhibitory to Nitrosomonas but may be inhibitory toNitrobacter. Therefore, nitrification was seen to proceed to the stage of $\mathrm{NO}_{2}-\mathrm{N}$ only and the major portion of $\mathrm{NO}_{\mathrm{x}}-\mathrm{N}$ consisted of nitrite. All these observations indicated the sensitivity of nitrifiers to $\mathrm{pH}$ changes. On the other hand, COD removal did not change with such $\mathrm{pH}$ decreases since heterotrophs were much more resistant.

In SCFB Run 3 the ratio of leachate was increased to $20 \%$ and $72 \%$ of the initial COD originated from leachate. This did not only increase the organic and nitrogenous strength of the feed, but also caused a higher level of inhibitory or toxic substances. As seen in Table 2a, in the effluent of the AS reactor the residual TCOD and SCOD amounted to $618 \pm 23$ and $435 \pm 15$ $\mathrm{mg} \cdot \ell^{-1}$, respectively. These high values suggested that additional treatment techniques would be required if the leachate ratio was increased. As seen in Fig. 3a and Table 2a, a considerable reduction was observed in the final TCOD and SCOD concentrations in the case of PAC addition to the AS+PAC reactor. During the period from 0 to $16 \mathrm{~d}$ and after the slug PAC dose on the $16^{\text {th }}$ day, the effluent SCOD concentrations reached relatively lower values in the AS+PAC reactor compared to the AS reactor. These differences were also statistically significant. Generally, when the leachate ratio in the feed increased, the effect of PAC became more apparent. Also, the differences were more apparent in terms of effluent TCOD than SCOD since PAC improved sludge settleability and decreased the concentration of particulate matter contributing to TCOD. In all former batch runs (Aktas and Çeçen, 2001) and these SCFB runs a clearer effluent was observed in PAC sludges.

In each case, OUR usually proceeded at higher values in the $\mathrm{AS}+\mathrm{PAC}$ reactor than in the AS 
reactor and followed COD profiles (Fig. $3 b)$. This was also observed in previous batch studies (Aktas and Çeçen, 2001).

In SCFB Run 3, no recordable nitrification was observed both in the AS and AS+PAC reactors as evidenced from poor $\mathrm{NO}_{\mathrm{x}}-\mathrm{N}$ production (Fig. $3 \mathrm{c}$ ). The final $\mathrm{NH}_{4}-\mathrm{N}$ concentrations were as high as $222 \pm 22$ and $247 \pm 26 \mathrm{mg} \cdot \ell^{-1}$ in the AS and AS+PAC reactors, respectively. These differences in final ammonium nitrogen concentrations were significant at $95 \%$ confidence level (Table $2 b$, Fig. $3 c)$. Although the feed $\mathrm{pH}$ was about 7.46 in the AS reactor, as a result of aeration and $\mathrm{CO}_{2}$ stripping, pHincreased to values exceeding 9. In the AS+PAC reactor this increase was slightly less, resulting in less ammonia stripping. Correspondingly, in both reactors the free ammonia (FA) level was as high as 55 to $75 \mathrm{mg} \cdot \ell^{-1}$ at high $\mathrm{pH}$, resulting in inhibition of Nitrosomonas. Thus, an increase in leachate ratio also caused a severe nitrification inhibition. At this leachate ratio of $20 \%$ even PAC addition could not relieve this inhibition as seen from the results belonging to the $\mathrm{AS}+\mathrm{PAC}$ reactor.

In SCFB Run 4 the leachate ratio was $13.3 \%$ as seen in Table $2 a$ and $b$ and $59 \%$ of the initial COD originated from leachate. In the AS+PAC reactor a constant PAC concentration of 2000 $\mathrm{mg} \cdot \ell^{-1}$ was maintained during the first $9 \mathrm{~d}$ of operation (Fig. 4a). The biggest differences between the AS and AS+PAC reactors were observed in this run. The statistical analysis of effluent TCOD and SCOD shown in Fig. 4a indicated a significant difference between these two reactors. On the $9^{\text {th }}$ day a shock PAC addition was made to the $\mathrm{AS}+\mathrm{PAC}$ reactor yielding an additional $2000 \mathrm{mg} \cdot \ell^{-1}$. The final TCOD in the AS+PAC reactor could be decreased further to $100 \mathrm{mg} \cdot \ell^{-1}$ by this addition, whereas this was at about 400 $\mathrm{mg} \cdot \ell^{-1}$ in the parallel AS reactor. The SCOD in the AS+PAC reactor decreased to $27 \mathrm{mg} \cdot \ell^{-1}$ whereas in the AS reactor this was at about $300 \mathrm{mg} \cdot \ell^{-1}$. PAC obviously adsorbed a great portion of the non-biodegradable COD.

As in other runs, in the AS+PAC reactor, OUR profiles remained at a considerably higher level than in the AS reactor (Fig. 4b).

As seen in Fig. 4c after the start of intermittent feeding, in the first $5 \mathrm{~d}$ of operation, no nitrification was observed in both reactors as evidenced from $\mathrm{NO}_{x}$ $\mathrm{N}$ profiles. In this period, free ammonia
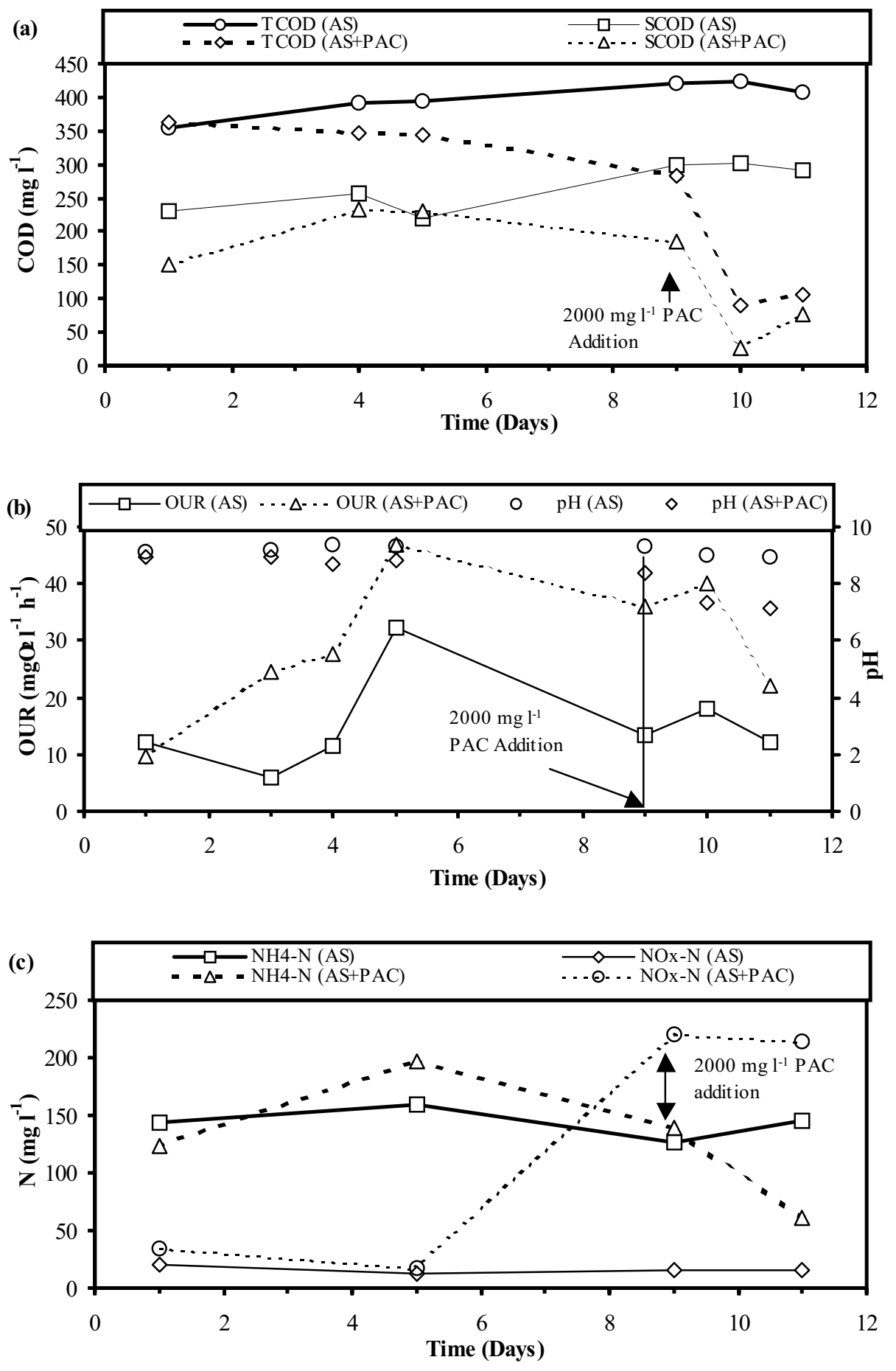

Figure 4

Profiles after the start-up of SCFB Run 4 in AS and AS+PAC reactors (with initial PAC conc. of $2000 \mathrm{mg} \cdot \ell^{1}$ in AS+PAC reactor and feed concentrations of TCOD $1854 \mathrm{mg} \cdot \ell^{1}, S C O D 1$ $626 \mathrm{mg} \cdot \ell^{1}, T K N 406 \mathrm{mg} \cdot \ell^{1}, \mathrm{NH}_{4}-\mathrm{N} 345 \mathrm{mg} \cdot \ell^{1}, N O_{x}-\mathrm{N} 15 \mathrm{mg} \cdot \ell^{1}$, and feed $\mathrm{pH}$ of 7.46)
(a) Final total COD (TCOD) and soluble COD (SCOD) concentrations
(b) OURs and $\mathrm{pH}$ in the reactors
(c) Final $\mathrm{NH}_{4}-\mathrm{N}$ and $\mathrm{NO}_{x}-\mathrm{N}$ concentrations 

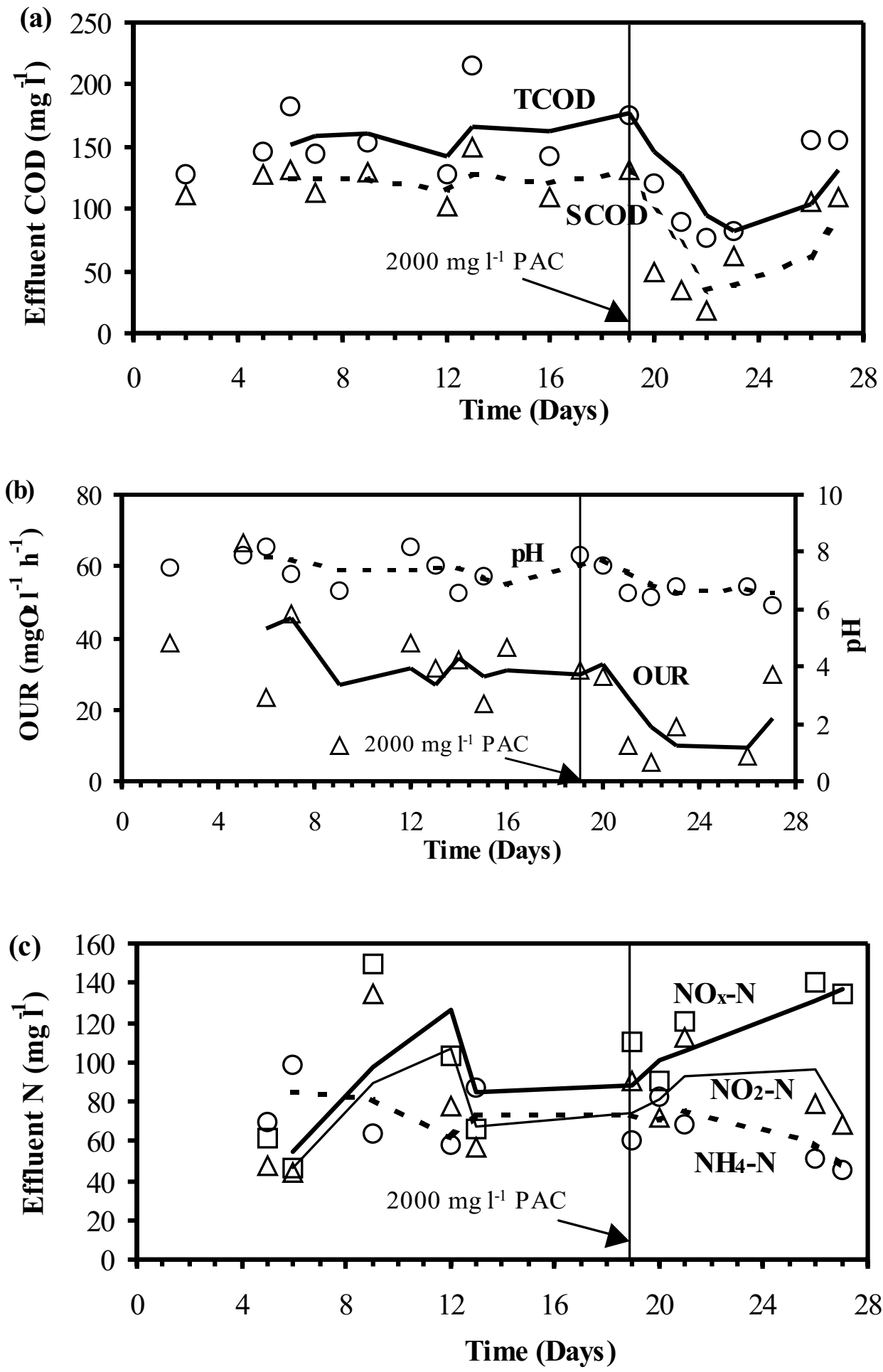

Figure 5

Profiles in PERIOD I of CF operation (with feed concentrations of TCOD $1255 \mathrm{mg} \cdot \ell^{1}, S C O D 1020$ $\mathrm{mg} \cdot \ell^{1}, \mathrm{TKN} 215 \mathrm{mg} \cdot \ell^{1}, \mathrm{NH}_{4}-\mathrm{N} 205 \mathrm{mg} \cdot \ell^{1}, \mathrm{NO}_{x}-\mathrm{N} 15 \mathrm{mg} \cdot \ell^{1}$, and feed $\mathrm{pH}$ of 7.38)

(a) Effluent total COD (TCOD) and soluble COD (SCOD) concentrations

(b) OURs and $\mathrm{pH}$ in the reactor

(c) Effluent $\mathrm{NH}_{4}-\mathrm{N}, \mathrm{NO}_{x}-\mathrm{N}$ and $\mathrm{NO}_{2}-\mathrm{N}$ concentrations
(FA) concentrations in the AS reactor (38 to $\left.69 \mathrm{mg} \cdot \ell^{-1}\right)$ and in the $\mathrm{AS}+\mathrm{PAC}$ reactor $\left(32\right.$ to $\left.42 \mathrm{mg} \cdot \ell^{-1}\right)$ were high and contributed to inhibition of Nitrosomonas. On the other hand, with PAC addition to the AS+PAC reactor not only was $\mathrm{NH}_{4}-\mathrm{N}$ removal improved, but also the $\mathrm{NO}_{\mathrm{x}} \mathrm{N}$ production rate was raised to $0.072 \mathrm{~g} \mathrm{NO}-\mathrm{N} \cdot \mathrm{g}$ $\operatorname{MLVSS}^{-1} \cdot \mathrm{d}^{-1}$. This increased nitrification was accompanied by a decrease in $\mathrm{pH}$ and free ammonia after the $9^{\text {th }}$ day. Increased COD and ammonium removals were the causes of higher OUR levels measured in the mixed liquor of the AS+PAC reactor (Fig. 4b). The positive effect of PAC on COD removal was immediately observed from the start-up. The later improvement in nitrification indicated that nitrifiers were much more sensitive to toxic and inhibitory shocks than heterotrophs. However, also in this run the major portion of $\mathrm{NO}_{\mathrm{x}}-\mathrm{N}$ in the AS+PAC reactor consisted of $\mathrm{NO}_{2}-\mathrm{N}$. In spite of PAC addition, $\mathrm{NO}_{2}-\mathrm{N}$ concentrations exceeded even $200 \mathrm{mg} \cdot \ell^{-1}$ as seen in Fig. 4c. Also previous batch studies had revealed that nitrite build-up was considerable in leachate treatment (Aktas and Çeçen, 2001).

\section{Continuous-flow (CF) activated sludge operation}

In Table 3 a the results about COD removal are presented. Arelatively low standard deviation was obtained in steady-state values and substrate removal rate was calculated using these values as shown in Eq. (1). Similarly, Table $3 \mathrm{~b}$ summarises the results achieved in terms of nitrogen.

\section{Period I}

In this period between 0 to $27 \mathrm{~d}$, the feed concentrations were: TCOD: $1255 \mathrm{mg} \cdot \ell^{-1}$, SCOD: $1020 \mathrm{mg} \cdot \ell^{-1}$, TKN: $215 \mathrm{mg} \cdot \ell^{-1}$, $\mathrm{NH}_{4}-\mathrm{N}: 205 \mathrm{mg} \cdot \ell^{-1}$ and $\mathrm{NO}_{\mathrm{x}}-\mathrm{N}: 15$ $\mathrm{mg} \cdot \ell^{-1}$. The loading rate was as 0.44 gTCOD $\cdot g M L V S S-1 \cdot \mathrm{d}^{-1}$. The effluent TCOD and SCOD concentrations are shown in Fig. 5a. The steady-state TCOD and SCOD concentrations in this period were about $161 \pm 28 \mathrm{mg} \cdot \ell^{-1}$ and $124 \pm 15 \mathrm{mg} \cdot \ell^{-1}$, respectively. 

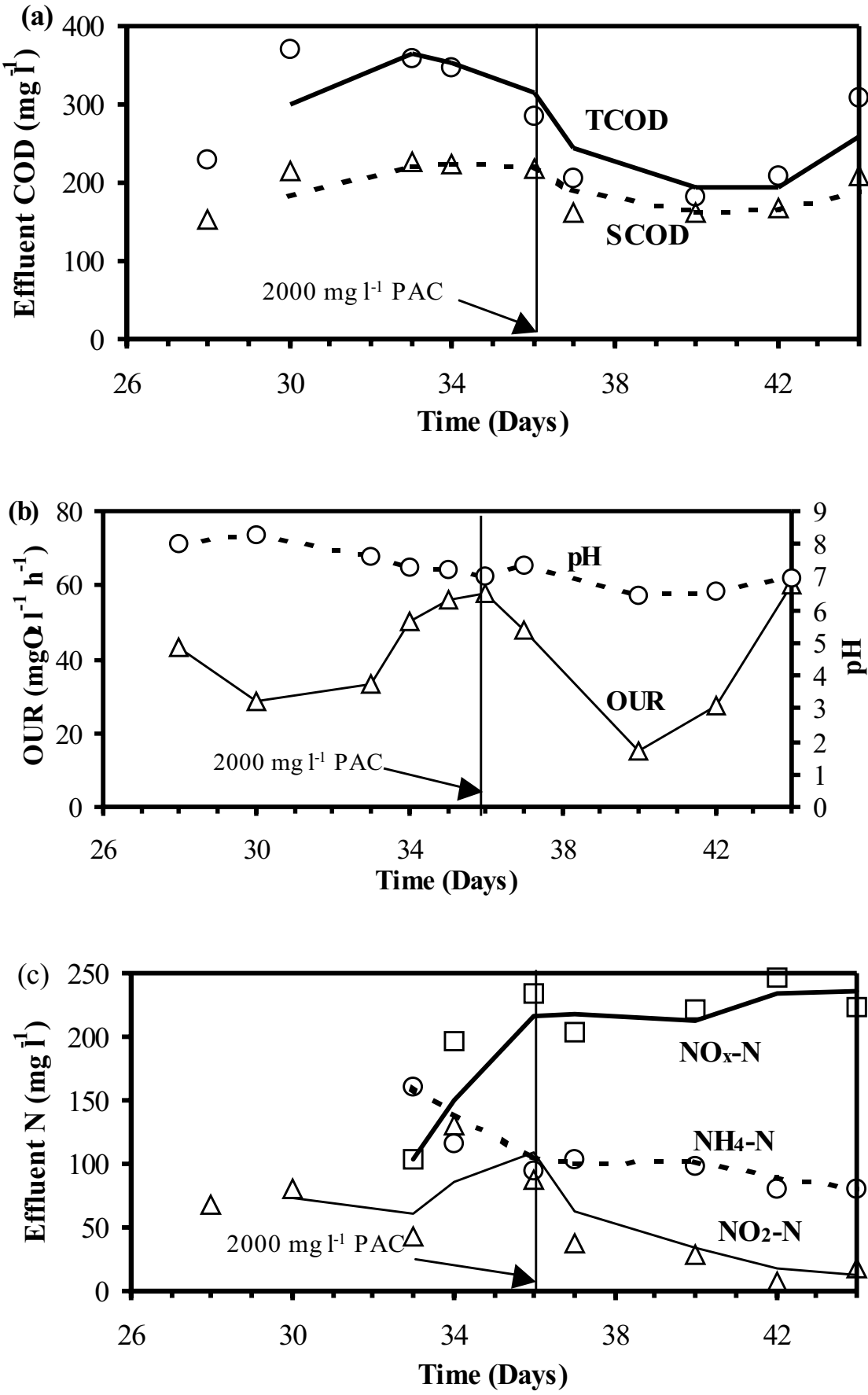

Figure 6

Profiles in PERIOD II of CF operation (with feed concentrations of TCOD $1854 \mathrm{mg} \cdot \ell^{1}$, SCOD $1626 \mathrm{mg} \cdot \ell^{1}, \mathrm{TKN} 406 \mathrm{mg} \cdot \ell^{1}, \mathrm{NH}_{4}-\mathrm{N} 345 \mathrm{mg} \cdot \ell^{1}, \mathrm{NO}_{x}-\mathrm{N} 15 \mathrm{mg} \cdot \ell^{1}$, and feed $\mathrm{pH}$ of 7.46 )

(a) Effluent total COD (TCOD) and soluble COD (SCOD) concentrations

(b) OURs and $\mathrm{pH}$ in the reactor

(c) Effluent $\mathrm{NH}_{4}-\mathrm{N}, \mathrm{NO}_{x}-\mathrm{N}$ and $\mathrm{NO}_{2}-\mathrm{N}$ concentrations
The latter was similar to the final SCOD of SCFB Runs 1 and 2, showing that SCFB operation could simulate continuous-flow operation in that respect. In the period before PAC addition ( 0 to $19 \mathrm{~d}$ ) the effluent stream contained non-biodegradable COD originating from leachate.

The slug PAC addition on the $19^{\text {th }}$ day led to an immediate effect (Fig. 5a) and in the effluent the mean TCOD decreased from $161 \pm 28 \mathrm{mg} \cdot \ell^{-1}$ to $92 \pm 20 \mathrm{mg} \cdot \ell^{-1}$, and the mean SCOD decreased from $124 \pm 15 \mathrm{mg} \cdot \ell^{-1}$ to $41 \pm 18 \mathrm{mg} \cdot \ell^{-1}$, respectively. This effect of PAC lasted for about $4 \mathrm{~d}$, but then the effluent COD tended to increase to levels before PAC addition (Fig. 5a), indicating the loss of effectiveness after saturation of PAC.

The OUR profiles illustrated in Fig. $5 b$ exhibited a pattern similar to COD profiles. OUR was higher when micro-organisms were exposed to higher concentrations of biodegradable substrate in the reactor. When biodegradable COD decreased, OUR tended to decrease (Fig. 5c). Hence, it was deduced that OUR serves as a sensitive parameter in reflecting the responses to substrate changes and PAC additions, especially in the case of continuous-flow operation.

In the period from 0 to $19 \mathrm{~d}, \mathrm{NH}_{4}-\mathrm{N}$ removal and $\mathrm{NO}_{\mathrm{x}}-\mathrm{N}$ production were similar to SCFB operation. In this period, the second step of nitrification, conversion of nitrite to nitrate, was inhibited and a major portion of $\mathrm{NO}_{\mathrm{x}}-\mathrm{N}$ existed in the form of nitrite (Fig. 5c) as in former SCFB Runs 1 and 2.

As seen from the $\mathrm{NH}_{4}-\mathrm{N}$ and $\mathrm{NO}_{x}-\mathrm{N}$ profiles in Fig. $5 \mathrm{c}$ and the values in Table $3 \mathrm{~b}$, after the PAC addition on the $19^{\text {th }}$ day $\mathrm{NH}_{4}-\mathrm{N}$ removal and $\mathrm{NO}_{x}-\mathrm{N}$ production rates increased. $\mathrm{NO}_{\mathrm{x}}-\mathrm{N}$ production rate (Table $3 \mathrm{~b}$ ) far exceeded those reached in SCFB runs in which nitrification improvement was not visible. The reason was the saturation of PAC with biodegradable and non-inhibitory organic matter and loss of effectiveness in those SCFB runs. In spite of this increased $\mathrm{NO}_{\mathrm{x}}-\mathrm{N}$ production, $\mathrm{NO}_{2}-\mathrm{N}$ concentrations did not rise apparently in continuous-flow operation, showing that inhibition of Nitrobacter was prevented to some extent after PAC addition. This was not observed in any of the former batch (Aktas and Çeçen, 2001) and SCFB Runs.

\section{Period II}

In this period lasting from 26 to $36 \mathrm{~d}$ the reactor received a feed with an increased leachate ratio ( $13.3 \%$ by volume) as seen in Table $3 \mathrm{a}$ and $3 \mathrm{~b}$. The feed concentrations were: TCOD:1 $854 \mathrm{mg} \cdot \ell^{-1}$, SCOD: 1626 $\mathrm{mg} \cdot \ell^{-1}, \mathrm{TKN}: 406 \mathrm{mg} \cdot \ell^{-1}, \mathrm{NH}_{4}-\mathrm{N}: 345 \mathrm{mg} \cdot \ell^{-1}$ and $\mathrm{NO}_{\mathrm{x}} \mathrm{N}: 15 \mathrm{mg} \cdot \ell^{-1}$. The loading rate was $1.25 \mathrm{gTCOD} \mathrm{gMLVSS}^{-1} \cdot \mathrm{d}^{-1} .59 \%$ of this 
COD loading was attributed to leachate-COD.

No new PAC had been added since the $19^{\text {th }}$ day of operation. In spite of this fact, the effect of PAC seemed to last longer in comparison to SCFB operation. As seen in Table 3a, the steadystate effluent TCOD and SCOD concentrations were about $340 \pm 39$ $\mathrm{mg} \cdot \ell^{-1}$ and $221 \pm 5 \mathrm{mg} \cdot \ell^{-1}$, respectively. It was seen that PAC became saturated and the effluent SCOD concentrations tended to increase slightly on days 34 to 36 (Fig. 6a). The new PAC addition on the $36^{\text {th }}$ day improved COD removal further. After this PAC addition, TCOD and SCOD were again decreased to $198 \pm 15 \mathrm{mg} \cdot \ell^{-1}$ and $165 \pm 3 \mathrm{mg} \cdot \ell^{-1}$, respectively (Fig. 6a, Table $3 \mathrm{a}$ ).

Generally, the effect of PAC was more pronounced in continuous-flow operation than in SCFB operation. This difference was attributed to the difference in operating conditions. In a continuous-flow reactor at steady-state, PAC was always exposed to much lower effluent concentrations than the influent. On the other hand, due to the once-a-day feeding pattern in the SCFB reactor, PAC was initially exposed to high substrate levels and probably became saturated with biodegradable COD, thereby decreasing its effectiveness.

The main differences between SCFB and CF operations were then observed when the ratio of leachate increased. In the SCFB reactors, micro-organisms were exposed to higher concentrations of toxic and inhibitory organics after each once-a-day feeding. However, in a CF reactor they were exposed to lower toxic and inhibitory concentrations due to the more steady operation and therefore a better COD removal was observed. In both SCFB and CF operations, however, PAC was not bioregenerated, at least not under the conditions of this study. Also in other studies a combination of PAC and biological treatment seemed not to be synergistic (Çeçen, 1994; Xiaojian et al., 1991). If bioregeneration did take place, the filled PAC pores would be purified leading to further substrate uptake even if no new PAC was added. Also in batch reactors no visible bioregeneration of PAC was observed (Aktas and Çeçen, 2001). Bioregeneration is a means of reducing PAC requirements. If this is not obviously seen like in our case, PAC should be continuously added to the reactor in order to bring about a permanent removal in COD and other parameters.

Also during this period OUR values (Fig. 6b) usually followed the COD pattern, but remained at a higher level than in PERIOD I since in PERIOD II substrate loads and effluent concentrations were higher. Also, the enhancement of $\mathrm{NO}_{x}-\mathrm{N}$ production may have contributed to this higher OUR level in this period.

$\mathrm{NO}_{x}-\mathrm{N}$ and $\mathrm{NO}_{2}-\mathrm{N}$ concentrations did not change significantly in the first 5 to $6 \mathrm{~d}$ after the increase of leachate ratio (Fig. 6c). But on the $34^{\text {th }}$ day an improvement in nitrification was observed. Obviously some time was required to reach steady-state and acclimate nitrifiers to new feeding conditions. After the shock PAC dose on the $36^{\text {th }}$ day, both $\mathrm{NH}_{4}-\mathrm{N}$ removal and $\mathrm{NO}_{\mathrm{x}}-\mathrm{N}$ production increased (Fig. 6c). A greater percentage of $\mathrm{NH}_{4}-\mathrm{N}$ was converted into $\mathrm{NO}_{x}-\mathrm{N}$. As seen in Table $3 \mathrm{~b}$, the maximum $\mathrm{NO}_{x}-\mathrm{N}$ production rate amounted to $0.160 \mathrm{gNO}_{\mathrm{x}}-\mathrm{N} \cdot \mathrm{gMLVSS}{ }^{-1} \cdot \mathrm{d}^{-1}$ which far exceeded those achieved in SCFB operation. Figure $6 \mathrm{~b}$ also shows that effluent $\mathrm{pH}$ decreased apparently accompanying nitrification. But the most striking effect of PAC was the achievement of complete nitrification. A smaller fraction of effluent $\mathrm{NO}_{x}-\mathrm{N}$ consisted of $\mathrm{NO}_{2}-\mathrm{N}$ and the $\mathrm{NO}_{2}-\mathrm{N}$ concentration was decreased from above $100 \mathrm{mg} \cdot \ell^{-1}$ to about $10 \mathrm{mg} \cdot \ell^{-1}$ indicating that inhibition of Nitrobacter had been almost completely prevented (Fig. 6c).

Throughout this continuous-flow operation, FA concentrations were below $6 \mathrm{mg} \cdot \ell^{-1}$. FA concentrations between 1 and $6 \mathrm{mg} \cdot \ell^{-1}$ might have contributed to Nitrobacter inhibition, but this was also observed in periods when FA was below $1 \mathrm{mg} \cdot \ell^{-1}$ that would not be inhibitory. Hence, an additional factor in nitrification inhibition seemed to be also the presence of inhibitory organics and metals in leachate.

\section{Conclusions}

The study brought a novel approach in combined leachate and domestic wastewater treatment by showing how and under which circumstances the negative impact of leachate could be relieved by PAC addition in semi-continuous and continuous-flow operations. As the ratio of leachate in the feed increased, the positive effect of PAC became more apparent and total COD and soluble COD concentrations could be decreased to low levels. At increased leachate ratios nitrification became generally more inhibited, primarily due to the increase in free ammonia. With PAC addition this inhibition could be relieved to some extent. Generally PAC addition had a more pronounced effect on nitrification than on organic carbon removal.

The study also emphasised the differences between SCFB and $\mathrm{CF}$ operations. The positive effect of $\mathrm{PAC}$ on $\mathrm{COD}$ reduction and nitrification was more striking in CF operation than in SCFB operation. For practical purposes the results in SCFB operation implied that under intermittent substrate loadings the effect of PAC would be less compared to steady CFoperation. Another observation made during the study was that PAC was not bioregenerated. Therefore a continuous PAC addition was necessary when PAC became saturated. The depletion of organic matter could be successfully monitored by OUR measurements which was best observed in CF operation.

\section{Acknowledgements}

The support of the Research Fund of Bogaziçi University (Project No. 98HY02) is gratefully acknowledged.

\section{References}

AKTAS Ö (1999) Powdered Activated Carbon Addition to Activated Sludge in the Treatment of Landfill Leachate. M.Sc. Thesis, Bogaziçi Univ.

AKTAS Ö and ÇEÇEN F (2001) Activated carbon addition to batch activated sludge reactors in the treatment of landfill leachate. $J$. of Chem. Technol. and Biotechnol. (in print).

ANTHONISEN A, LOEHR RC, PRAKASAM TBS and SRINATH EG (1976) Inhibition of nitrification by ammonia and nitrous acid. J. Water Pollut. Control Fed. 48 835-852.

ARBUCKLE W and GRIGGS AA (1982) Determination of biomass MLVSS in PACT sludges. J. Water Pollut. Control Fed. 54 15531557.

ÇEÇEN F (1994) Activated carbon addition to activated sludge in the treatment of kraft pulp bleaching wastes. Water Sci. Techol. 30 183-192.

ÇEÇEN F and ÇAKIROGLU D (2001) Impact of landfill leachate on the co-treatment of domestic wastewater. Biotechnol. Lett. (in print).

JONGE RJ, BREURE AM and VAN ANDEL JG (1996) Bioregeneration of powdered activated carbon (PAC) loaded with aromatic compounds. Water Res. 30 875-882.

KANG SJ, ENGLERT CJ, ASTFALK TJ and YOUNG MA (1990) Treatment of leachate from a hazardous waste landfill. In: $44^{\text {th }}$ Purdue Ind. Waste Conf. Proc., Purdue Univ. Lewish Publishers, Michigan. 573-579.

KIM D, MIYAHARA T and NOIKE T (1997) Effect of C/N ratio on the bioregeneration of biological activated carbon. Water Sci. Techol. 36 239-249.

KRUG MN and HAM RK (1997) Analyses of long-term leachate characteristics. Proc. of the 6th Int. Landfill Symp., Sardinia. 117-131. 
MARQUEZ MC and COSTA C (1996) Biomass concentration in PACT process. Water Res. 30 2079-2085.

NG A, STENSTROM K and MARRS DR(1987) Nitrification enhancement in the powdered activated carbon-activated sludge process for the treatment of petroleum refinery wastewaters. J. Water Pollut. Control Fed. 59 199-211.

NG A and STENSTROM MK (1987) Nitrification in powdered activated carbon-activated sludge process. J. Env. Eng. 113 1285-1301.

ORHANSKY F and NARKIS N (1997) Characteristics of organics removal by PACT simultaneous adsorption and biodegradation. Water Res. 31 391-398.

QUASIM SR and CHIANG W (1994) Sanitary Landfill Leachate: Generation, Control and Treatment. Technomic Publishing Co., Lancaster.
SPECCHIA V and GIANETTO A (1984) Powdered activated carbon in an activated sludge treatment plant. Water Res. 18 133-137.

STANDARD METHODS (1989) Standard Methods for the Examination of Water and Wastewater (17 $7^{\text {th }}$ edn.), APHA, AWWA and WPCF, USA.

SUBLETTE KL, SNIDER EH and SYLVESTER ND (1982) A review of the mechanism of powdered activated carbon enhancement of activated sludge treatment. Water Res.16 1075-1082.

U.S. EPA MANUAL (1995) Ground Water and Leachate Treatment Systems. EPA/625/R-94/005, Ohio.

XIAOJIAN Z, ZHANSHENG W and XIASHENG G (1991) Simple combination of biodegradation and carbon adsorption-mechanism of the biological activated carbon process. Water Res. 25 165-172. 